\title{
THE ENVIRONMENTAL RESEARCH OF THE PNEUMATIC PARACHUTE RESCUE SYSTEM FOR UAV VERTICAL TAKE-OFF AND LANDING
}

\author{
Badania środowiskowe pneumatycznego \\ spadochronowego systemu ratunkowego dla BSP pionowego \\ startu i lądowania
}

\begin{abstract}
The subject of the article is the environmental research of the Pneumatic Parachute Rescue System (PPRS) for an unmanned aerial vehicle, in which the parachute will be initiated from the reservoir by means of compressed carbon dioxide $\left(\mathrm{CO}_{2}\right)$ stored in a special chamber. The research team has developed a program for researching the natural environment to simulate the conditions that may occur during the operation of an unmanned aerial vehicle and thus the Pneumatic Parachute Rescue System. UAV emergency scenarios were developed in which the developed rescue system should operate.
\end{abstract}

Keywords: parachute, UAV, environmental research

Streszczenie: Przedmiotem artykulu sq badania środowiskowe Pneumatycznego Spadochronowego Systemu Ratunkowego (PSSR) dla bezzalogowego statku powietrznego, w którym wyrzucenie spadochronu z zasobnika inicjowane jest za pomoca sprężonego dwutlenku wegla $\left(\mathrm{CO}_{2}\right)$, zmagazynowanego w specjalnej komorze. Zespót badawczy opracowat program badań środowiskowych, mających na celu zasymulowanie warunków, jakie moga zaistnieć w trakcie eksploatacji bezzalogowego statku powietrznego i co za tym idzie Pneumatycznego Spadochronowego Systemu Ratunkowego. Przygotowano scenariusze sytuacji awaryjnych BSP, dla których opracowany system ratunkowy powinien być skuteczny.

Słowa kluczowe: spadochron, BSP, badania środowiskowe 


\section{Introduction}

The development of unmanned aerial vehicles (UAVs) is an important problem to increase the safety level of unmanned rotor platforms. Currently unmanned operators in the Polish airspace they are not formally obliged to use parachute rescue systems.

The development trend is increasing the level of safety in the commercial use of unmanned rotor platforms. Currently, unmanned aerial vehicle users operating in the Polish airspace are still not formally obliged to use parachute rescue systems. This situation is not favorable from the point of view of the safe use of unmanned platforms. For example, in France such systems are required. The French Civil Aviation Authority - CAA already issued a regulation on the safe operation of unmanned aircraft for professionals in 2017.

The analysis of the content of this document shows that every UAV operator who operates an aircraft with a mass exceeding $2 \mathrm{~kg}$ is obliged to install an emergency parachute landing system, together with an acoustic system warning against collision with the ground. According to the ordinance of the French Civil Aviation Authority, the kinetic energy of UAV at the time of falling to the ground cannot exceed 69J [6]. Countries such as Chile, Peru, Dominican Republic and Switzerland, following the example of France, imposed on the user the obligation to install emergency parachute landing systems to increase safety [1].

The Swiss post has been using drones to provide parcel delivery services since the second quarter of 2018. Flights are made between hospital departments where blood samples are transported. During one such flight an air accident happened. On January 25, 2019, a UAV weighing about $10 \mathrm{~kg}$ carrying laboratory samples across Lake Zurich was forced to initiate a controlled emergency landing and landed on the water. The Swiss Transport Safety Council (STSB) has determined the cause of the incident. According to the final STSB report, this short circuit led to a BSP emergency landing. Safety mechanisms worked properly, UAV initiated the emergency landing itself. To this end, UAV stops the engines and opens the parachute. The drone descends to the ground, emitting a high sound and bright flashing lights.

Observing the global directions of legislative work, there is a high probability that the Polish Civil Aviation Authority will oblige operators to install systems allowing for safe emergency landing of unmanned aircraft.

\section{Pneumatic parachute rescue system}

The idea of the project implemented since 2018 at ITWL was to design, manufacture and test a Pneumatic Parachute Rescue System (PPRS) for an unmanned aerial vehicle. The project was implemented thanks to funds obtained from the Ministry of Science and Higher Education intended for young scientists.

The essence of the concept of the system lies in the fact that the rescue parachute is thrown from the container using compressed gas (carbon dioxide $-\mathrm{CO}_{2}$ ). The trigger 
mechanism of the PPRS in which part of the drive is electric servo via the conversion of rotary motion to linear causes to put pressure the firing pin on the valve of the chamber. The pressure of the spire on the valve is the opening of the compressed gas chamber. After filling the reservoir with expanded gas, the parachute follows. The research problem concerns the practical integration of mechatronic systems for use in a specific flying facility (multicopter) with strictly defined volatile and technical characteristics. The construction of the gas ejector was presented on the cross-section of the model made in Solid WORKS software (fig. 1) [2,3,6,7].

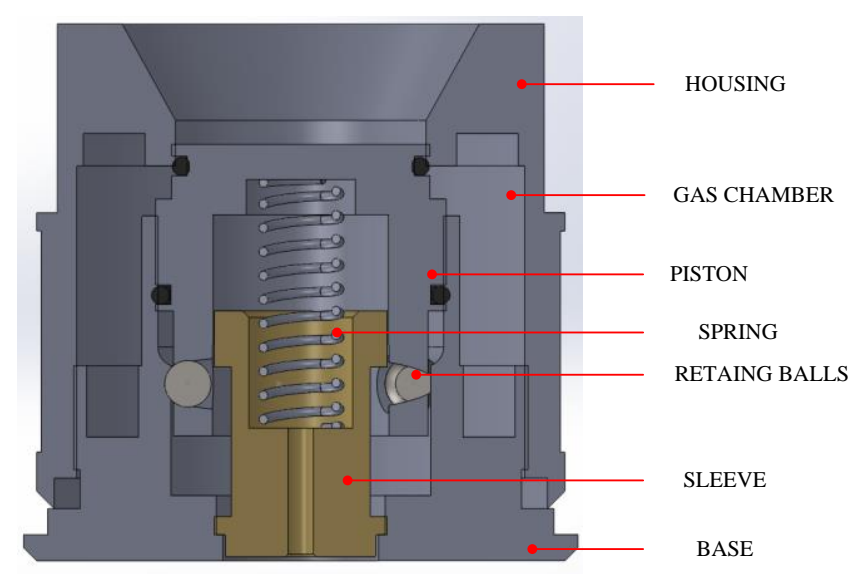

Fig. 1. Cross section of gas ejector model with marked elements [6]

View of the entire system is shown in fig. 2.
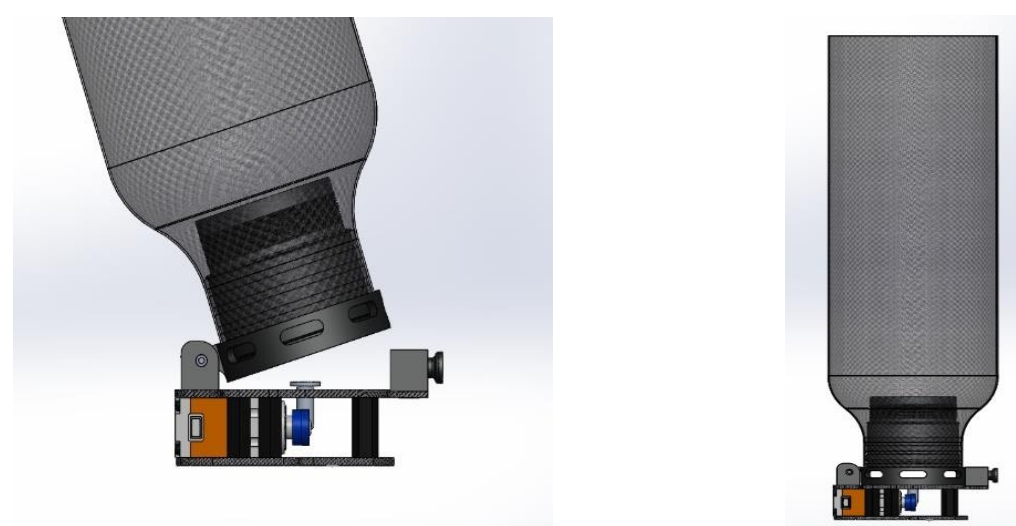

Fig. 2. View of the pneumatic parachute rescue system 


\section{Assumptions for environmental research}

Determination of the environmental working conditions of the PPRS in the aspect of safety of its use on BSP vertical take-off and landing (multi-rotor BSP). Environmental tests were carried out based on the military standard NO-06-A107: 2005. The scope of research included: determining the resistance of PPRS to changes in temperature, pressure and humidity. The research method consists in simulating working conditions in an environment with variable temperature, pressure and humidity in a climatic chamber and determining whether the rescue system will work properly under these conditions.

Tests of resistance to environmental factors were carried out at the ITWL Mechanical and Climate Exposure Laboratory. The laboratory is accredited by the Polish Center for Accreditation with the number AB 133 (accreditation since 1997) and accreditation in the field of Defense and Security (accreditation since 2008) with the number 10 / MON / 2017. The laboratory's activity is based on conducting tests of resistance and durability of aviation equipment to the impact of environmental factors. The technical data of the chambers used during the tests are presented in table 1.

Table 1

Technical data of equipment used during tests

\begin{tabular}{||l|l||}
\hline \multicolumn{2}{|c|}{ TEST CHAMBER 1 } \\
\hline Type & Angelantoni CH1200 TC VT 5L \\
\hline Manufacturer & Angelantoni Industrie SpA (Italy) \\
\hline Dimensions of the test chamber & $1000 \times 1070 \times 1140 \mathrm{~mm}$ \\
\hline Temperature range & from $-70^{\circ} \mathrm{C}$ to $+180^{\circ} \mathrm{C}$ \\
\hline Relative humidity range & from $3 \%$ to $98 \%$ \\
\hline \multicolumn{2}{|l|}{ TEST CHAMBER 2 } \\
\hline Type & Angelantoni UY $1000 \mathrm{C}$ \\
\hline Manufacturer & Angelantoni Industrie $\mathrm{SpA}$ (Italy) \\
\hline Dimensions of the test chamber & $1000 \times 1000 \mathrm{x} 1000 \mathrm{~mm}$ \\
\hline Temperature range & from $-70^{\circ} \mathrm{C} \mathrm{to}+100^{\circ} \mathrm{C}$ \\
\hline Lowered pressure & down to $20 \mathrm{hPa}$ \\
\hline Relative humidity range & from $20 \%$ to $95 \%$ \\
\hline
\end{tabular}

During the PSSR research on the impact of environmental factors, the following were adopted:

- increased ambient temperature during operation $-+40^{\circ} \mathrm{C}$ and $+50^{\circ} \mathrm{C}$,

- reduced ambient temperature during operation $-0^{\circ} \mathrm{C},-20^{\circ} \mathrm{C}$ and $-40^{\circ} \mathrm{C}$,

- normal ambient temperature during operation $-+20^{\circ} \mathrm{C}$,

- resistance to increased humidity - above $90 \%$ relative humidity at $+25^{\circ} \mathrm{C}$, without condensation,

- reduced pressure resistance $-467 \mathrm{hPa}$.

The tests were carried out according to the following steps: 
1. UAV emergency scenarios have been developed for which the PPRS should be effective.

2. The accredited laboratory simulated environmental conditions that may occur during the implementation of this type of mission.

3. The parachute ejection energy was determined based on the shooting test.

Based on literature [5,8] and own experience, the research team formulated four basic flight scenarios for unmanned aerial vehicle vertical takeoff and landing. Environmental research was intended to simulate the working conditions of the PPRS in the following situations a UAV flight equipped with PPRS:

1. Unmanned aircraft flight at a given temperature in the range of $-40^{\circ} \mathrm{C}$ to $+50^{\circ} \mathrm{C}$.

2. Unmanned aircraft flight at high altitude at reduced pressure.

3. Flight in tropical conditions, i.e. at a temperature of $+25^{\circ} \mathrm{C}$ and relative humidity of $96 \%$ and at a temperature above $+50^{\circ} \mathrm{C}$ and humidity relative $98 \%$.

4. Flight at a reduced temperature of $-20^{\circ} \mathrm{C}$, then BSP crossing a rain cloud and flight again at a reduced temperature of $-20^{\circ} \mathrm{C}$.

\section{Results}

The first part of the research focused on simulating temperature conditions (scenario No. 1), and then checking whether the system would function properly. According to the research methodology described in military standards NO-06-A107:2005 and NO-06A103:2005 each temperature test lasted at least 2 hours (requirement for devices whose weight does not exceed $2 \mathrm{~kg}$ ). A series of tests were carried out in the range from $-40^{\circ} \mathrm{C}$ to $+50^{\circ} \mathrm{C}$ which is illustrated by charts from the climate chamber registration system (figs. 3 and 4). 


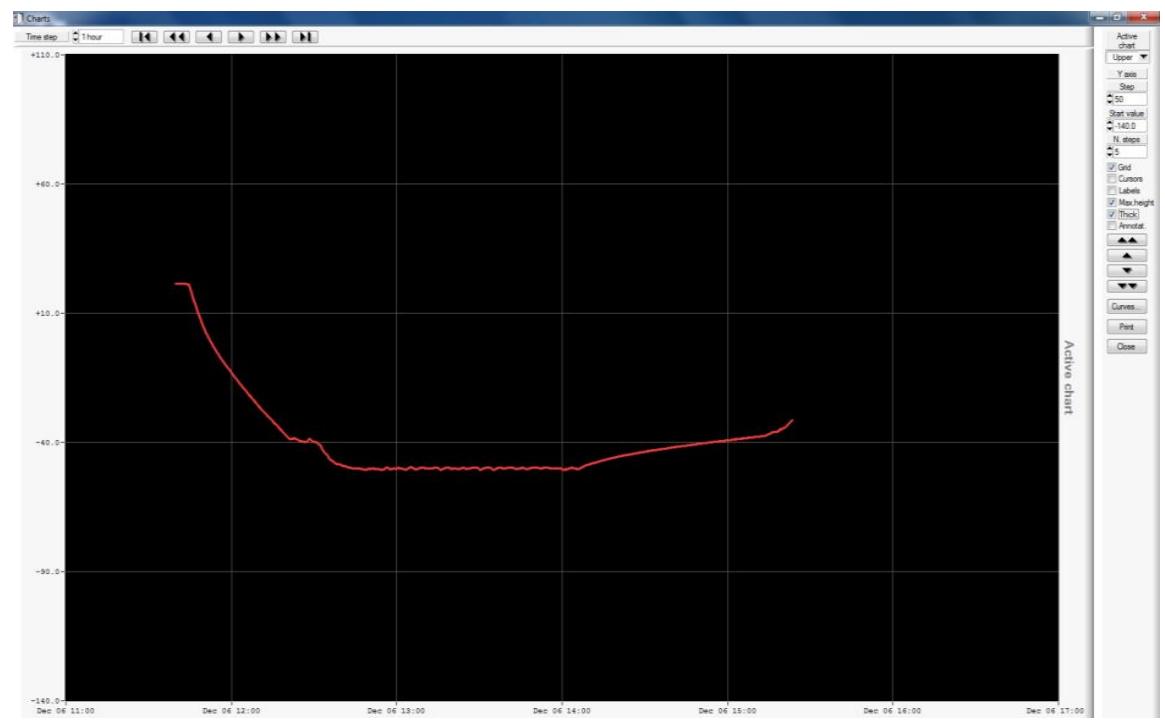

Fig. 3. Climate exposure $-40^{\circ} \mathrm{C}$

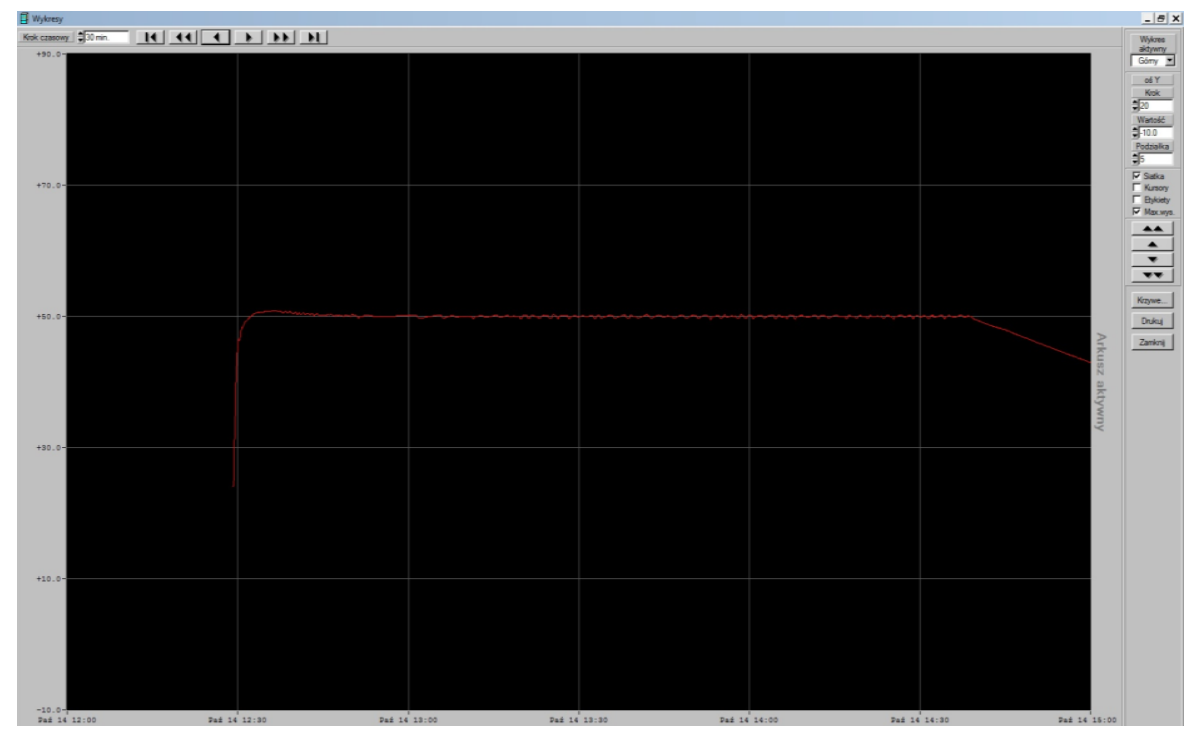

Fig. 4. Climate exposure $+50^{\circ} \mathrm{C}$

In the next research step, the PPRS was exposed to reduced pressure (scenario 2). Based on the defense standard NO-06-A103:2005, the maximum value of the environmental factor was $467 \mathrm{hPa}$, which corresponds to using the device at an altitude of up to about 6000 meters above sea level. The illustration of the sample is the figure below (fig. 5) 


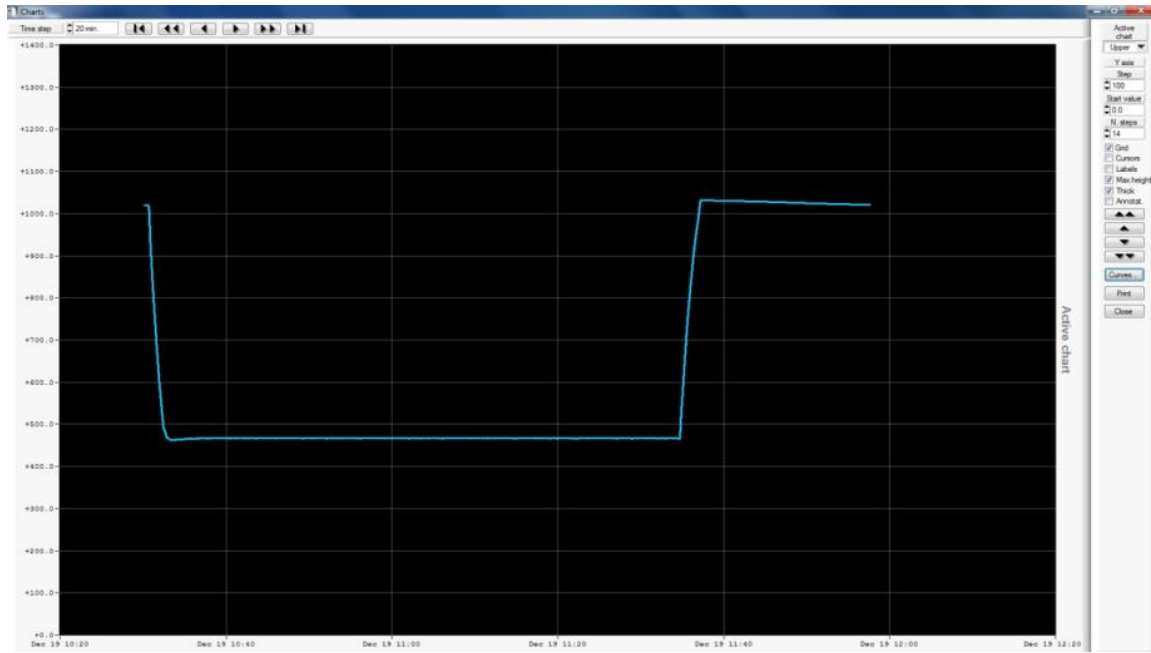

Fig. 5. Exposure to reduced pressure $467 \mathrm{hPa}$

Then flights were simulated in "tropical" climate conditions (scenario No. 3), which is reflected in figs. 6 and 7.

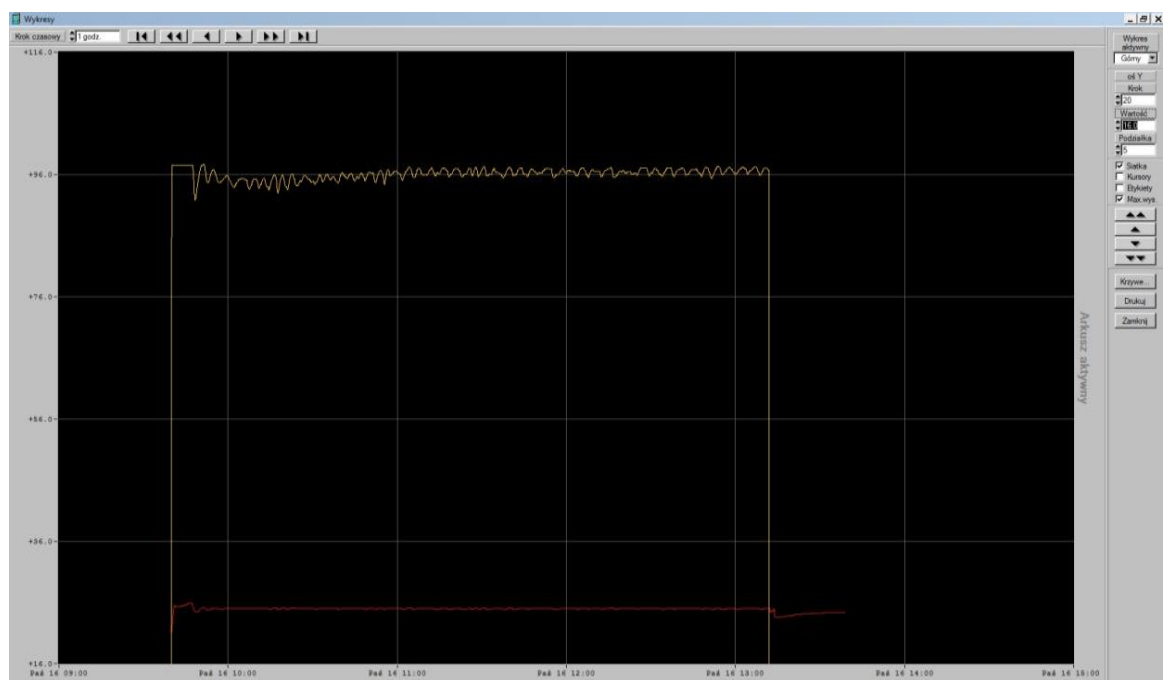

Fig. 6. Exposure to elevated relative humidity of $96 \%$ at temperature $25^{\circ} \mathrm{C}$ 


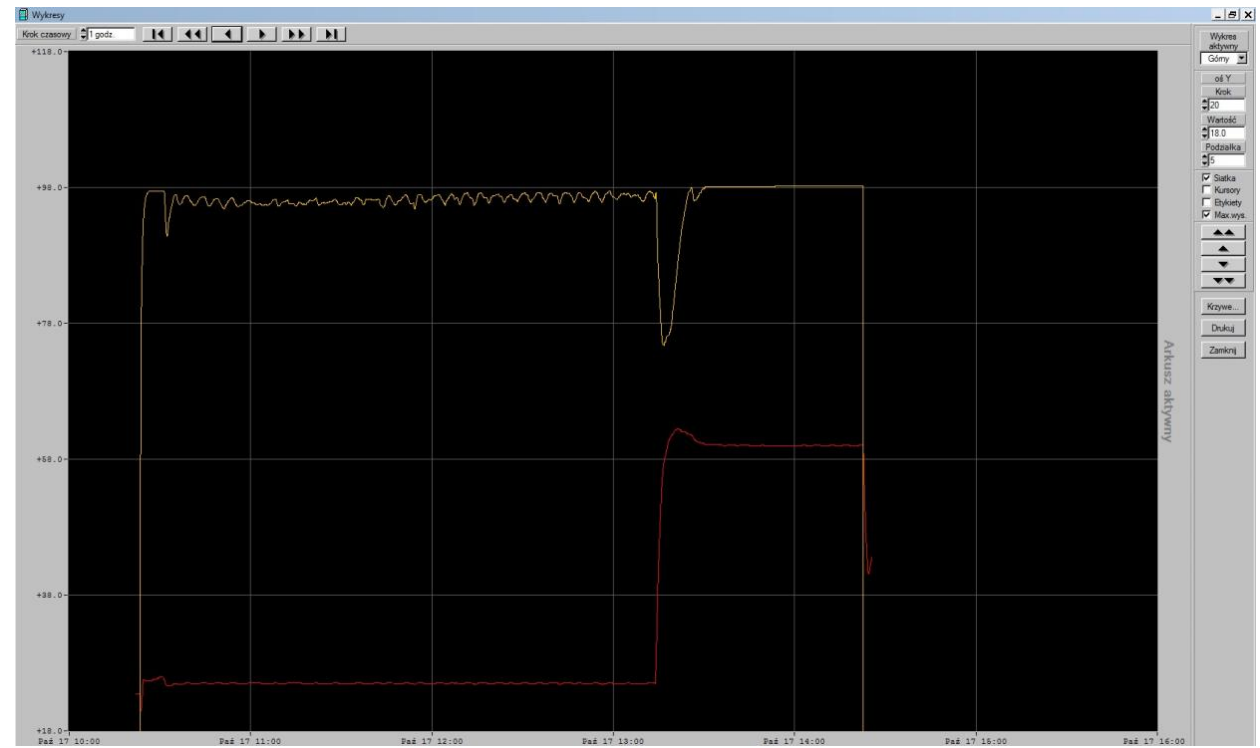

Fig. 7. Exposure to elevated relative humidity of $98 \%$ at a temperature above $50^{\circ} \mathrm{C}$

The last stage of the research was to simulate flights in which ice may occur in the device (scenario 4). The device was exposed to low temperature, then a spray of water was applied to the device with the sprayer and the device was exposed to low temperature again. The external appearance of the device after the test is shown in fig. 8 .
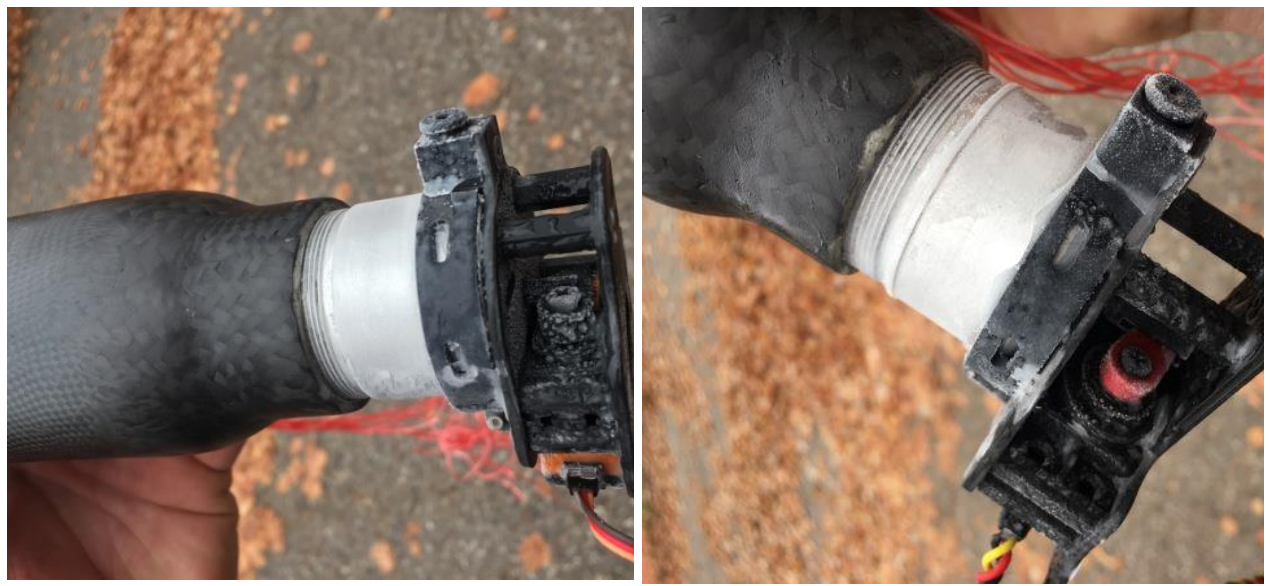

Fig. 8. View of the PPRS after the test according to scenario No. 4

In order to determine whether the system is sensitive to any of the environmental factors tested and to confirm that the PPRS works effectively in the assumed conditions, 
a test stand has been developed to determine the speed of launching the parachute along with recording movement parameters (fig. 9) [4].

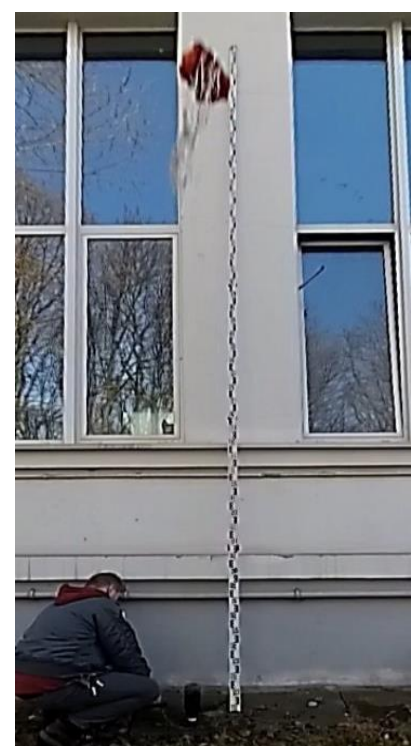

Fig. 9. Test stand for determining the speed of parachute launch'

Each time after performing environmental exposure, the PPRS was tested at a previously prepared stand. The whole attempt was recorded, and then in the program for frame-by-frame analysis of the image, the time in which the parachute covered the distance of 5 meters was determined. On this basis, the average parachute speed was determined for each of the shots from the relationship (1):

$$
V=\frac{s}{t}
$$

where:

$\mathrm{s}-$ path of the parachute after launch $-5 \mathrm{~m}$;

$\mathrm{t}$ - time needed for parachute to overcome $5 \mathrm{~m}$.

The kinetic energy of the parachute was determined from the results obtained and based on the relationship (2).

where:

$$
E=\frac{m v^{2}}{2}
$$

$m$ - parachute mass $-0.2116 \mathrm{~kg}$;

$v$-average speed of the parachute on the road $5 \mathrm{~m}[\mathrm{~m} / \mathrm{s}]$. 
The results of calculations of the kinetic energy of the parachute for various temperature exposures are summarized in table 2.

Table 2

Calculation results of the kinetic energy of the parachute depending on the temperature

\begin{tabular}{|r|r|r|r|r|r||}
\hline & $\begin{array}{c}\text { Temperature } \\
{\left[{ }^{\circ} \mathbf{C}\right]}\end{array}$ & \multicolumn{1}{c|}{$\begin{array}{c}\text { Gas mass } \\
{[\mathbf{g}]}\end{array}$} & \multicolumn{1}{c|}{$\begin{array}{c}\text { Time } \\
{[\mathbf{s}]}\end{array}$} & \multicolumn{1}{c|}{$\begin{array}{c}\text { Average Speed } \\
{[\mathbf{m} / \mathbf{s}]}\end{array}$} & \multicolumn{1}{c|}{$\begin{array}{c}\text { Kinetic energy } \\
{[\mathbf{J}]}\end{array}$} \\
\hline 1 & -40 & 1,99 & 0,31 & 16,13 & 27,52671602 \\
\hline 2 & -30 & 2,00 & 0,3 & 16,66 & 29,36538248 \\
\hline 3 & -20 & 2,06 & 0,3 & 16,66 & 29,36538248 \\
\hline 4 & -10 & 2,15 & 0,3 & 16,66 & 29,36538248 \\
\hline 5 & 0 & 2,06 & 0,26 & 19,23 & 39,12408882 \\
\hline 6 & 20 & 2,04 & 0,245 & 20,4 & 44,029728 \\
\hline 7 & 40 & 2,01 & 0,235 & 21,77 & 50,14210082 \\
\hline 8 & 50 & 2,03 & 0,2 & 25 & 66,125 \\
\hline
\end{tabular}

Environmental studies have shown that PPRS is temperature sensitive, as illustrated in fig. 10. At the same time, it should be recognized that in the entire temperature range examined, kinetic energy is sufficient for effective operation of the device.

\section{Kinetic energy as a function of temperature}

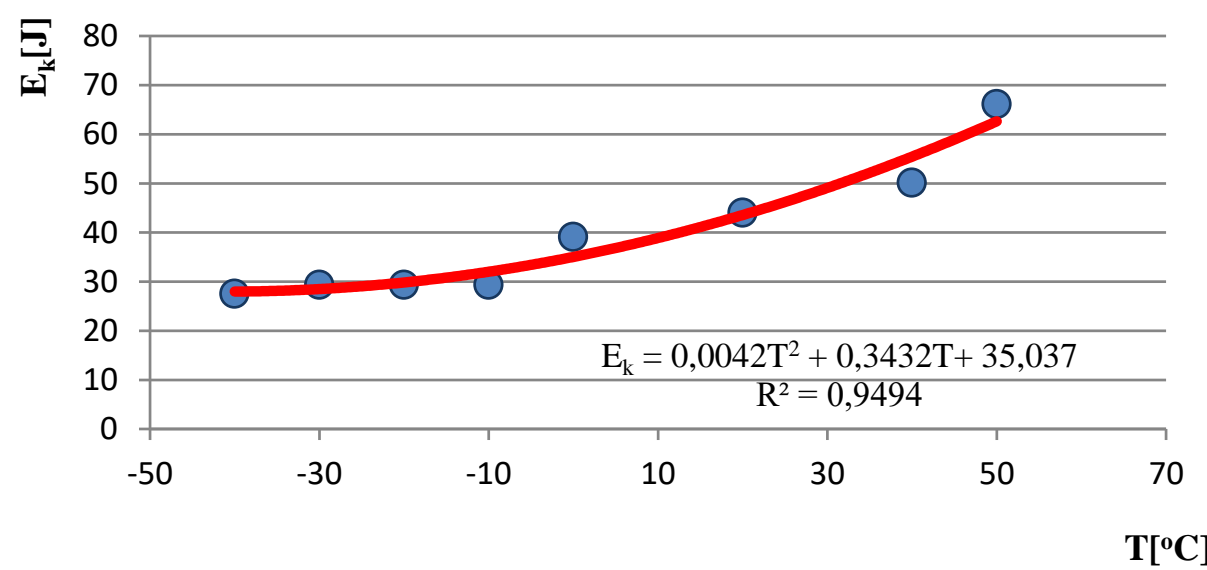

Fig. 10. Graph of kinetic energy dependence on temperature

In addition, the results of shooting in the remaining exposure cases, i.e. at reduced pressure and increased humidity, were analyzed. The research team did not note in the tested range of system sensitivity to both reduced pressure and increased humidity. 


\section{Conclusions}

Tests in simulated laboratory conditions have shown that the PPRS works correctly in the temperature range from $-20^{\circ} \mathrm{C}$ to $+50^{\circ} \mathrm{C}$, relative humidity $98 \%$ and at reduced pressure to $467 \mathrm{hPa}$. During research in the climatic chamber it was found that the Pneumatic Parachute Rescue System is suitable for use on BSP for vertical take-off and landing.

\section{References}

1. Biała Księga Rynku Bezzałogowych Statków Powietrznych, Ministerstwo Infrastruktury, Warszawa, luty 2019.

2. Grymek S.: Modele strumienia powietrza w pneumatyce. Politechnika Gdańska, Gdańsk 2012.

3. Jastrzębski G.: Description of the pneumatic work cycle of the starting unit of the UAV launcher. Journal of KONES, tom 4, nr 24, 2017.

4. Jastrzębski G.: Impact of opening time of the take-off pneumatic luncher main valve on take-off pressure losses. Journal of KONES, tom 23, nr 4, 2016.

5. Nawrat A.: Modelowanie i sterowanie bezzałogowych obiektów latających. Wydawnictwo Politechniki Śląskiej, 2009.

6. Szczepaniak P., Jóźko M., Włodarczyk J.: Koncepcja pneumatycznego spadochronowego systemu ratunkowego dla BSP pionowego startu i lądowania. Journal of KONBiN, vol. 49, iss. 2, 2019, DOI 10.2478/jok-2019-0026.

7. Szejnach W.: Napędy i sterowanie pneumatyczne. Wydawnictwo Naukowo-Techniczne, 1997.

8. Tomaszek H., Żurek J., Jasztal M.: Prognozowanie uszkodzeń zagrażających bezpieczeństwu lotów statków powietrznych. Wydawnictwo Naukowe Instytutu Technologii Eksploatacji - PIB, 2008. 


\section{BADANIA ŚRODOWISKOWE PNEUMATYCZNEGO SPADOCHRONOWEGO SYSTEMU RATUNKOWEGO DLA BSP PIONOWEGO STARTU I LĄDOWANIA}

\section{Wprowadzenie}

Wraz z rozwojem bezzałogowych statków powietrznych (BSP) coraz bardziej istotnym stał się rozwój zwiększania poziomu bezpieczeństwa wirnikowych platform bezzałogowych. Obecnie użytkownicy bezzałogowców, operujący w polskiej przestrzeni powietrznej nie są formalnie zobligowani do wykorzystania spadochronowych systemów ratunkowych. Sytuacja ta nie jest korzystna z punktu widzenia bezpieczeństwa użytkowania platform bezzałogowych. Dla przykładu we Francji wymagane są tego typu systemy. Francuski Urząd Lotnictwa Cywilnego - CAA już w 2017 r. wydał Rozporządzenie dotyczące bezpiecznej eksploatacji bezzałogowych statków powietrznych dla profesjonalistów. Z analizy treści tego dokumentu wynika, że każdy operator BSP, który operuje statkiem powietrznym o masie przekraczającej $2 \mathrm{~kg}$, jest zobligowany do montażu systemu awaryjnego lądowania na spadochronie, wraz z systemem akustycznym ostrzegającym przed kolizją z ziemią. Według rozporządzenia Francuskiego Urzędu Lotnictwa Cywilnego energia kinetyczna BSP w chwili upadku na ziemię nie może przekroczyć 69J [6]. Takie kraje jak: Chile, Peru, Dominikana czy Szwajcaria za przykładem Francji nałożyły na użytkownika obowiązek montażu systemów awaryjnego lądowania na spadochronie w celu zwiększenia poziomu bezpieczeństwa [1].

Szwajcarska poczta od II kwartału 2018 r. wykorzystuje drony do świadczenia usługi dostawy przesyłek. Loty wykonywane są pomiędzy oddziałami szpitali, gdzie transportowane są próbki krwi do badań. Podczas jednego z takich lotów zdarzył się wypadek lotniczy. 25 stycznia 2019 r., BSP o masie ok. $10 \mathrm{~kg}$, niosący próbki laboratoryjne przez Jezioro Zuryskie został zmuszony do zainicjowania kontrolowanego lądowania awaryjnego i wylądował na wodzie. Szwajcarska Rada ds. Bezpieczeństwa Transportu (STSB) ustaliła przyczynę incydentu. Według raportu końcowego STSB to zwarcie doprowadziło do awaryjnego lądowania maszyny. Mechanizmy bezpieczeństwa zadziałały prawidłowo, BSP sam zainicjował awaryjne lądowanie. W tym celu BSP zatrzymuje silniki i otwiera spadochron. Dron opada ku ziemi, emitując wysoki dźwięk oraz jasne migające światła.

Obserwując światowe kierunki prac legislacyjnych istnieje duże prawdopodobieństwo, że polski Urząd Lotnictwa Cywilnego zobliguje operatorów do montażu systemów pozwalających na bezpieczne awaryjne lądowanie bezzałogowego statku powietrznego. 


\section{Pneumatyczny spadochronowy system ratunkowy}

Ideą projektu realizowanego od $2018 \mathrm{r}$. w ITWL było zaprojektowanie, wykonanie i badania Pneumatycznego Spadochronowego Systemu Ratunkowego (PSSR) dla bezzałogowego statku powietrznego. Projekt realizowany był dzięki środkom pozyskanym z Ministerstwa Nauki i Szkolnictwa Wyższego przeznaczonych dla młodych naukowców.

Istota koncepcji systemu polega na tym, że spadochron ratunkowy wyrzucany jest z zasobnika za pomocą sprężonego gazu (dwutlenku węgla $-\mathrm{CO}_{2}$ ). Mechanizm wyzwalania PSSR, w którym elementem napędowym jest serwomechanizm elektryczny poprzez układ zamiany ruchu obrotowego na liniowy, powoduje wywarcie nacisku iglicy na zawór komory $\mathrm{CO}_{2}$. Efektem nacisku iglicy na zawór jest otwarcie komory ze sprężonym gazem. Na chwilę po wypełnieniu zasobnika spadochronowego rozprężonym gazem następuje wyrzut spadochronu ratunkowego. Budowa wyrzutnika gazowego została zaprezentowana na przekroju modelu wykonanego w oprogramowaniu Solid WORKS (rys. 1) $[2,3,6,7]$.

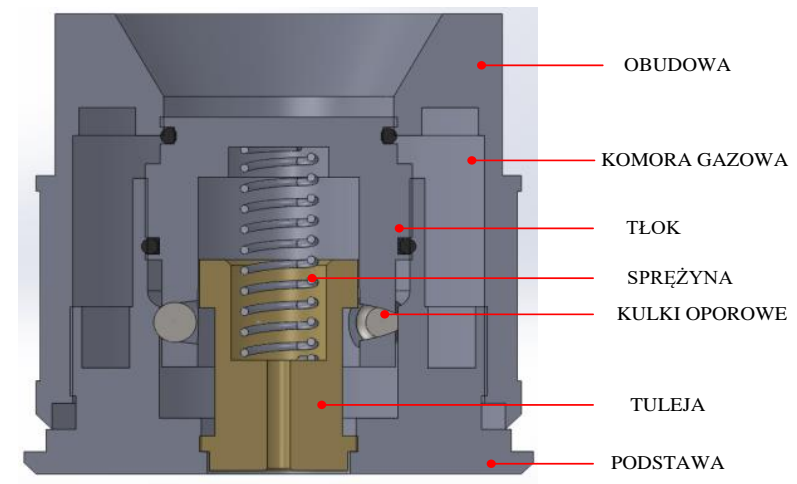

Rys. 1. Przekrój przez model wyrzutnika gazowego z oznaczonymi elementami [6]

Widok całego systemu przedstawia rys. 2 .
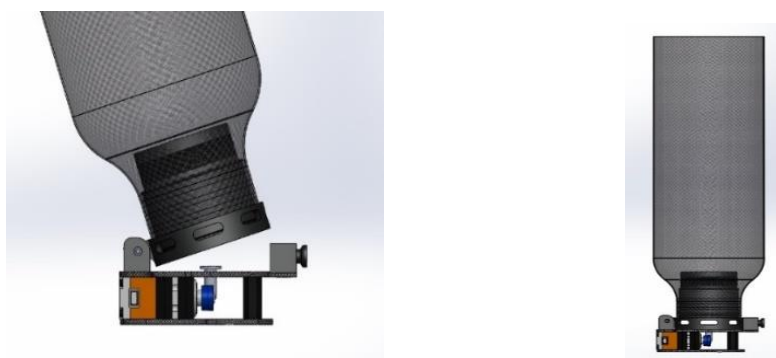

Rys. 2. Widok pneumatycznego spadochronowego systemu ratunkowego 


\section{Założenia do badań środowiskowych}

Problemem badawczym było określenie środowiskowych warunków pracy PSSR w aspekcie bezpieczeństwa jego użytkowania na BSP pionowego startu i lądowania (wielowirnikowe BSP). Badania środowiskowe przeprowadzono w oparciu zarówno o wiedzę ekspercką, jak i o normę wojskową NO-06-A107:2005. Zakres badań obejmował określenie odporności PSSR na zmiany temperatury, ciśnienia i wilgotności. Metoda badawcza polega na symulowaniu warunków pracy w środowisku ze zmienną temperaturą, ciśnieniem i wilgotnością w termobarokomorze oraz określeniu, czy system ratunkowy będzie w tych warunkach działał prawidłowo.

Badania odporności na oddziaływania czynników środowiskowych zostały przeprowadzone w Laboratorium Narażeń Mechanicznych i Klimatycznych ITWL. Laboratorium posiada akredytację Polskiego Centrum Akredytacji o numerze AB 133 (akredytacja od 1997 r.) oraz akredytację w zakresie Obronności i Bezpieczeństwa (akredytacja od 2008 r.) o numerze 10/MON/2017. Działalność Laboratorium opiera się na prowadzeniu badań odporności i wytrzymałości urządzeń lotniczych na oddziaływanie czynników środowiskowych. Dane techniczne komór użytkowanych podczas badań przedstawiono w tabeli 1.

Tabela 1

Dane techniczne wyposażenia używanego podczas badań

\begin{tabular}{||l|l||}
\hline \multicolumn{2}{|c||}{ KOMORA KLIMATYCZNO - WIBRACYJNA } \\
\hline Typ & Angelantoni CH1200 TC VT 5L \\
\hline Producent & Angelantoni Industrie SpA (Włochy) \\
\hline Wymiary komory prób & $1000 \times 1070 x 1140 \mathrm{~mm}$ \\
\hline Zakres temperatury & od $-70^{\circ} \mathrm{C}$ do $+180^{\circ} \mathrm{C}$ \\
\hline Zakres wilgotności względnej & od 3\% do 98\% \\
\hline \multicolumn{2}{|c||}{ KOMORA BAROKLIMATYCZNA } \\
\hline Typ & Angelantoni UY $1000 \mathrm{C}$ \\
\hline Producent & Angelantoni Industrie SpA (Włochy) \\
\hline Wymiary komory prób & $1000 x 1000 x 1000 \mathrm{~mm}$ \\
\hline Zakres temperatury & od $-70^{\circ} \mathrm{C}$ do $+100^{\circ} \mathrm{C}$ \\
\hline Obniżone ciśnienie & do $20 \mathrm{hPa}$ \\
\hline Zakres wilgotności względnej & od $20 \%$ do $95 \%$ \\
\hline
\end{tabular}

Podczas badań PSSR na oddziaływania czynników środowiskowych przyjęto:

- podwyższoną temperaturę otoczenia podczas pracy $-+40^{\circ} \mathrm{C}$ oraz $+50^{\circ} \mathrm{C}$,

- obniżoną temperaturę otoczenia podczas pracy $-0^{\circ} \mathrm{C},-20^{\circ} \mathrm{C}$ oraz $-40^{\circ} \mathrm{C}$,

- normalna temperatura otoczenia podczas pracy $-+20^{\circ} \mathrm{C}$,

- odporność na zwiększoną wilgotność - powyżej 90\% wilgotności względnej przy temperaturze $+25^{\circ} \mathrm{C}$, bez kondensacji,

- odporność na obniżone ciśnienie - $467 \mathrm{hPa}$. 
Badania zostały przeprowadzone według następujących kroków:

1. Opracowano scenariusze sytuacji awaryjnych BSP, dla których PSSR powinien być skuteczny.

2. W laboratorium akredytowanym symulowano warunki środowiskowe, mogące wystąpić podczas realizacji tego typu misji.

3. Wyznaczono energię wyrzutu spadochronu w oparciu o próbę strzelań.

Zespół badawczy na podstawie literatury [5,8] oraz własnego doświadczenia sformułował cztery podstawowe scenariusze lotu bezzałogowego statku powietrznego pionowego startu i lądowania. Badania środowiskowe miały na celu zasymulowanie warunków pracy PSSR w następujących sytuacjach lotu BSP wyposażonego w PSSR:

1. Lot bezzałogowego statku powietrznego przy danej temperaturze w zakresie od $-40^{\circ} \mathrm{C}$ do $+50^{\circ} \mathrm{C}$.

2. Lot bezzałogowego statku powietrznego na dużych wysokościach przy obniżonym ciśnieniu.

3. Lot $\mathrm{w}$ warunkach tropikalnych, tj. przy temperaturze $+25^{\circ} \mathrm{C}$ i wilgotności względnej $96 \%$ oraz przy temperaturze powyżej $+50^{\circ} \mathrm{C}$ i wilgotności względnej $98 \%$.

4. Lot przy obniżonej temperaturze $-20^{\circ} \mathrm{C}$, następnie przejście BSP przez chmurę deszczową oraz ponowny lot $\mathrm{w}$ obniżonej temperaturze $-20^{\circ} \mathrm{C}$.

\section{Wyniki badań}

Pierwsza część badań skupiała się na zasymulowaniu warunków temperaturowych (scenariusz nr 1), a następnie sprawdzenie, czy system będzie funkcjonował prawidłowo. Zgodnie z metodologią badań opisaną w normach wojskowych NO-06-A107:2005 oraz NO-06-A103:2005 każda próba temperaturowa trwała co najmniej 2 godziny (wymóg dla urządzeń, których waga nie przekracza $2 \mathrm{~kg}$ ). Przeprowadzono szereg testów w zakresie od $-40^{\circ} \mathrm{C}$ do $+50^{\circ} \mathrm{C}$ czego zobrazowaniem są wykresy z systemu rejestracji komór klimatycznych (rys. 3 i 4 ). 


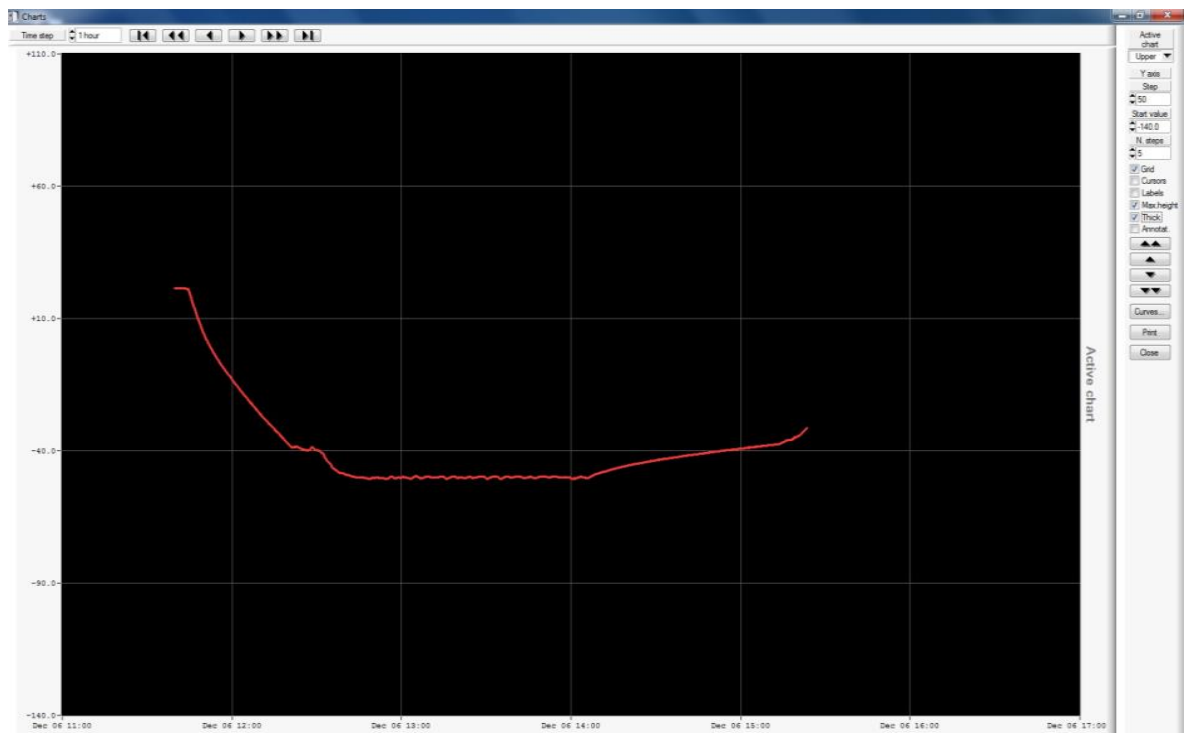

Rys. 3. Narażenie klimatyczne $-40^{\circ} \mathrm{C}$

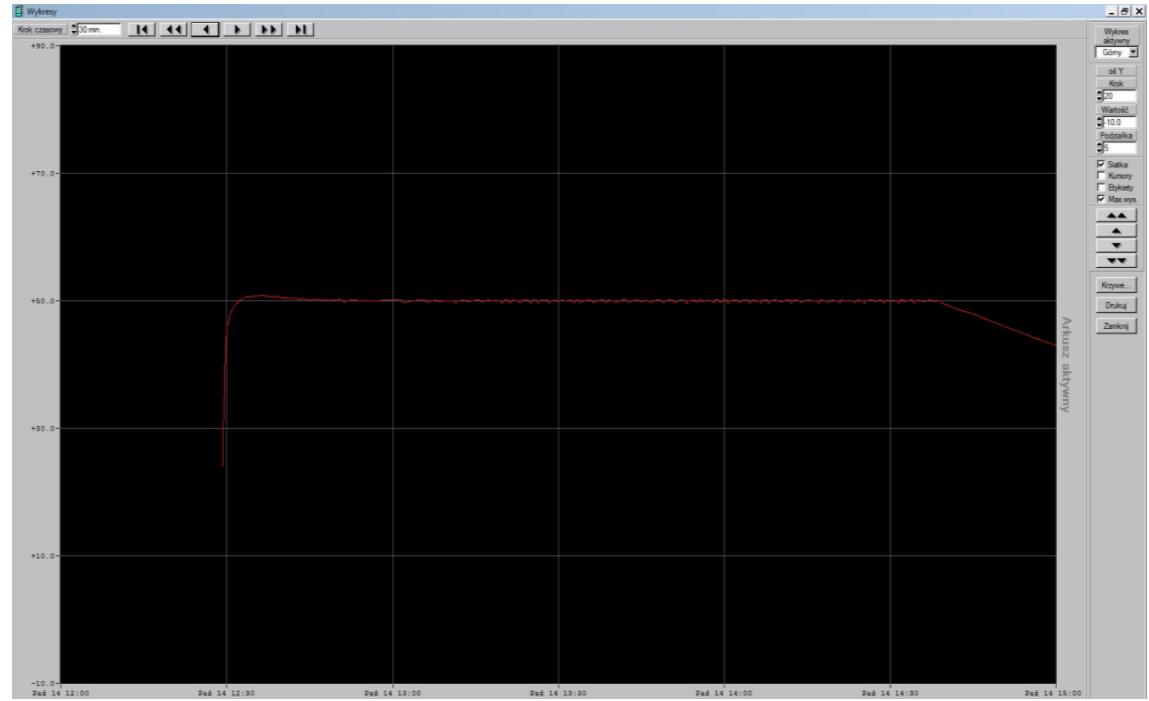

Rys. 4. Narażenie klimatyczne $+50^{\circ} \mathrm{C}$

W kolejnym kroku badawczym PSSR został poddany narażeniu na obniżone ciśnienie (scenariusz nr 2). Na podstawie normy obronnej NO-06-A103:2005 jako maksymalna wartość czynnika środowiskowego przyjęto wartość $467 \mathrm{hPa}$, co odpowiada użytkowaniu urządzenia na wysokości do około 6000 metrów n.p.m. Zobrazowaniem próby jest rysunek znajdujący się poniżej (rys. 5): 


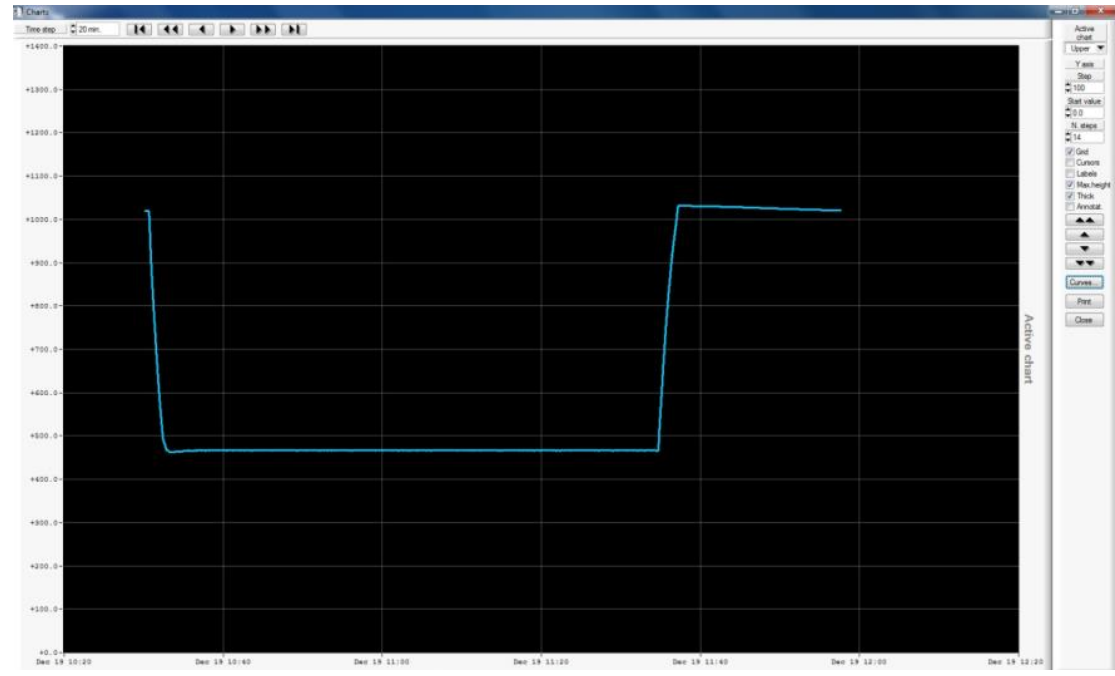

Rys. 5. Narażenie na obniżone ciśnienie $467 \mathrm{hPa}$

Następnie symulowano loty w warunkach ,tropikalnych” (scenariusz nr 3), czego odzwierciedleniem są rys. 6 i 7.

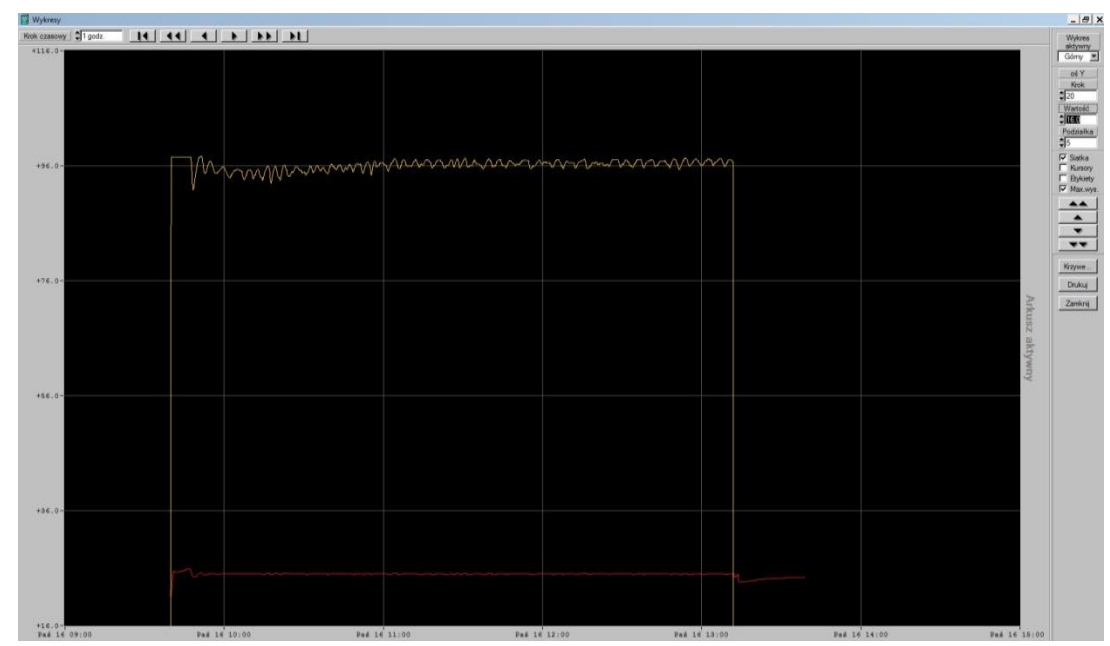

Rys. 6. Narażenie na podwyższoną wilgotność względną $96 \%$ przy temperaturze $25^{\circ} \mathrm{C}$ 


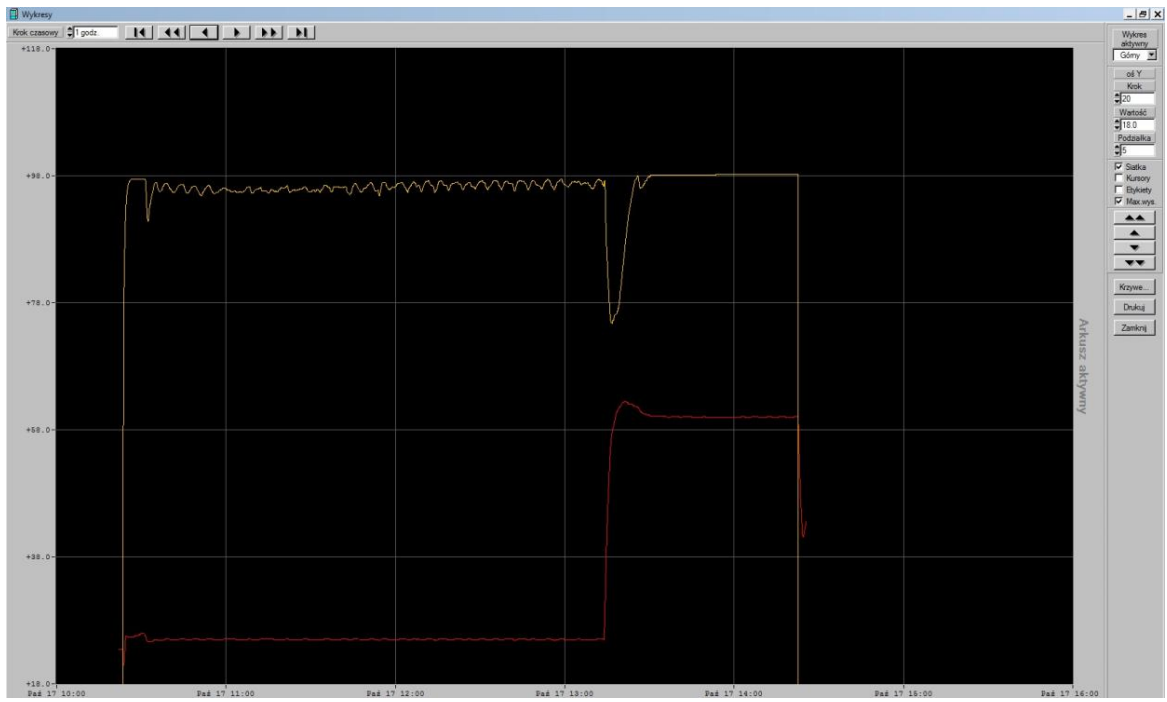

Rys. 7. Narażenie na podwyższoną wilgotność względną $98 \%$ przy temperaturze powyżej $50^{\circ} \mathrm{C}$

Ostatnim etapem badań było zasymulowanie lotów, w których może wystąpić oblodzenie urządzenia (scenariusz nr 4). Urządzenie poddano działaniu niskiej temperatury, następnie na urządzenie przy pomocy spryskiwacza została naniesiona warstwa wody oraz ponownie narażono urządzenie na niską temperaturę. Wygląd zewnętrzny urządzenie po przeprowadzonej próbie obrazuje rys. 8 .
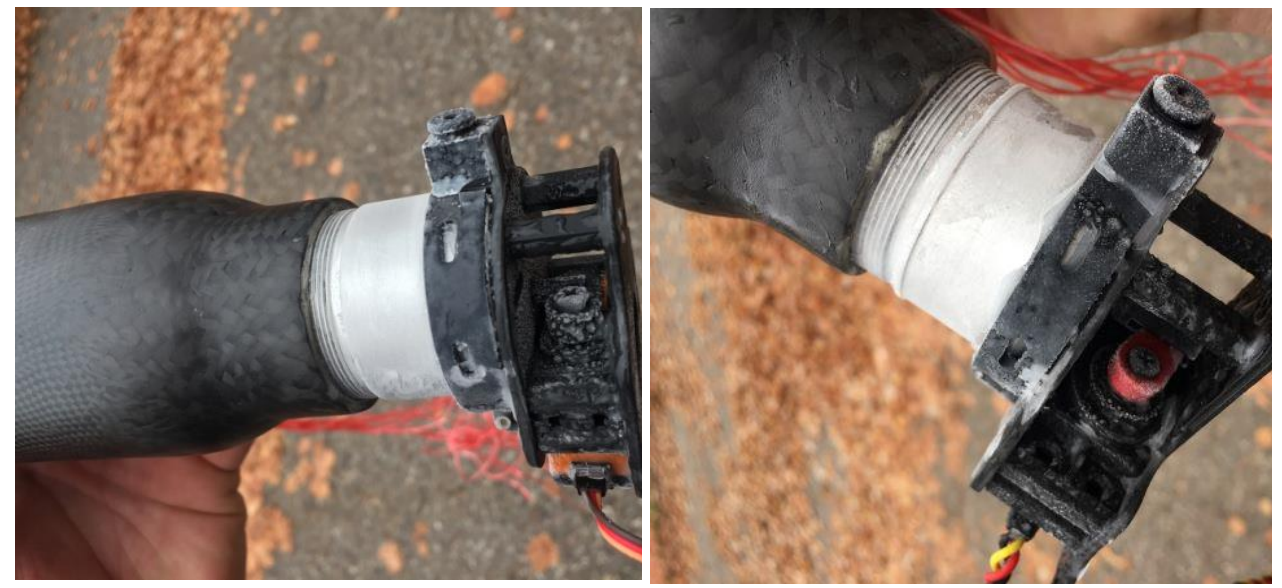

Rys. 8. Widok PSSR po przeprowadzonej próbie według scenariusza $\mathrm{nr} 4$

W celu określenia czy system wykazuje wrażliwość, na któryś z badanych czynników środowiskowych oraz potwierdzenia, że PSSR działa skutecznie w zakładanych warunkach 
opracowano stanowisko badawcze do wyznaczania prędkości wystrzeliwania spadochronu wraz z rejestracją parametrów ruchu (rys. 9) [4].

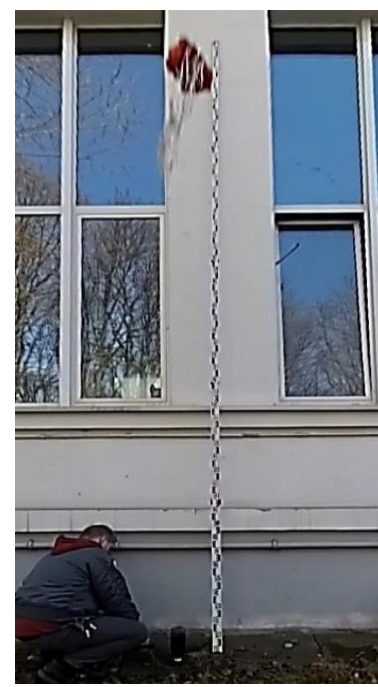

Rys. 9. Stanowisko badawcze do wyznaczania prędkości wystrzeliwania spadochronu

Każdorazowo po wykonaniu narażenia środowiskowego PSSR był badany na wcześniej przygotowanym stanowisku. Cała próba była nagrywana, a następnie w programie służącym do poklatkowej analizy obrazu wyznaczany był czas, w jakim spadochron pokonał drogę $5 \mathrm{~m}$. Na tej podstawie, wyznaczono średnią prędkość spadochronu dla każdego ze strzałów z zależności (1):

$$
V=\frac{s}{t}
$$

gdzie:

$\mathrm{s}$ - droga spadochronu po wystrzeleniu - przyjęto $5 \mathrm{~m}$,

$\mathrm{t}$ - czas, jakiego potrzebował spadochron na pokonanie $5 \mathrm{~m}$.

Z uzyskanych wyników oraz na podstawie zależności (2) określono energię kinetyczną spadochronu.

gdzie:

$$
E=\frac{m v^{2}}{2}
$$

$m$ - masa spadochronu $-0,2116 \mathrm{~kg}$,

$v$ - średnia prędkość spadochronu na drodze $5 \mathrm{~m}[\mathrm{~m} / \mathrm{s}]$. 
Wyniki obliczeń energii kinetycznej spadochronu dla różnych narażeń temperaturowych zestawiono w tabeli 2.

Tabela 2

Wyniki obliczeń energii kinetycznej spadochronu w zależności od temperatury

\begin{tabular}{|r|r|r|r|r|r||}
\hline \hline Lp. & $\begin{array}{c}\text { Temperatura } \\
{\left[{ }^{\circ} \mathbf{C}\right]}\end{array}$ & \multicolumn{1}{c|}{$\begin{array}{c}\text { Masa gazu } \\
{[\mathbf{g}]}\end{array}$} & \multicolumn{1}{c|}{$\begin{array}{c}\text { Czas } \\
{[\mathbf{s}]}\end{array}$} & \multicolumn{1}{c|}{$\begin{array}{c}\text { Prędkość } \\
{[\mathbf{m} / \mathbf{s}]}\end{array}$} & \multicolumn{1}{c|}{$\begin{array}{c}\text { Energia kinetyczna } \\
{[\mathbf{J}]}\end{array}$} \\
\hline 1 & -40 & 1,99 & 0,31 & 16,13 & 27,52671602 \\
\hline 2 & -30 & 2,00 & 0,3 & 16,66 & 29,36538248 \\
\hline 3 & -20 & 2,06 & 0,3 & 16,66 & 29,36538248 \\
\hline 4 & -10 & 2,15 & 0,3 & 16,66 & 29,36538248 \\
\hline 5 & 0 & 2,06 & 0,26 & 19,23 & 39,12408882 \\
\hline 6 & 20 & 2,04 & 0,245 & 20,4 & 44,029728 \\
\hline 7 & 40 & 2,01 & 0,235 & 21,77 & 50,14210082 \\
\hline 8 & 50 & 2,03 & 0,2 & 25 & 66,125 \\
\hline
\end{tabular}

Badania środowiskowe wykazały, że PSSR jest wrażliwy na temperaturę, co zobrazowano na rys.10. Jednocześnie należy uznać, że w całym badanym zakresie temperaturowym energia kinetyczna jest wystarczającą do skutecznego zadziałania urządzenia.

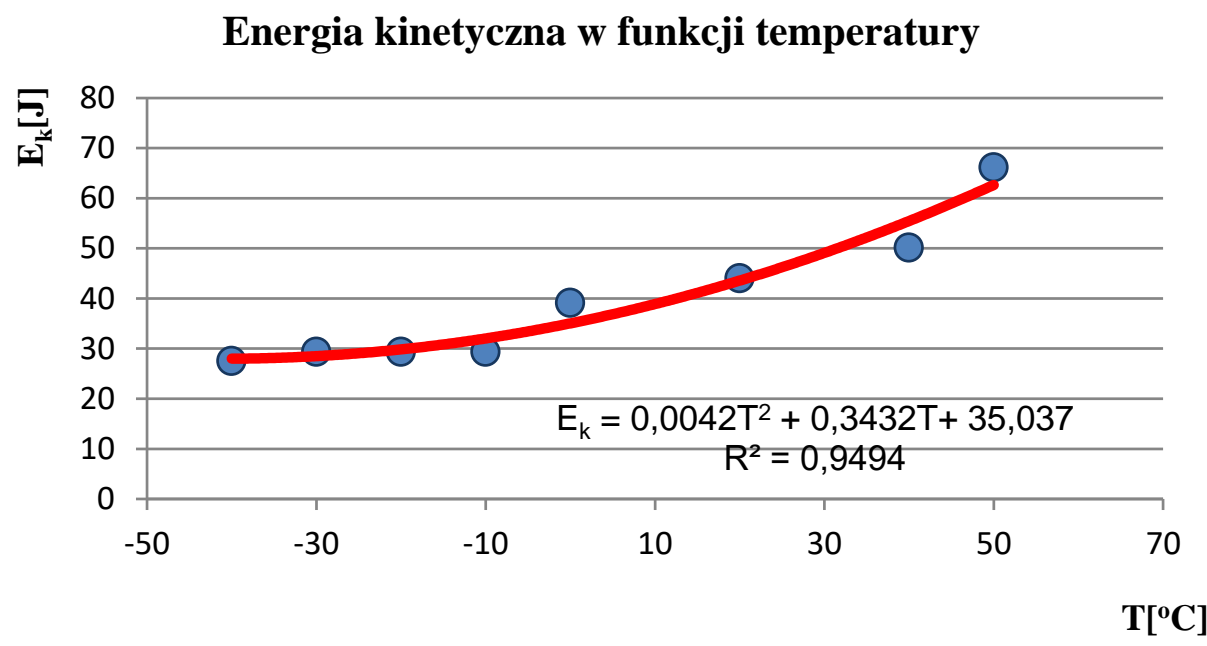

Rys. 10. Wykres zależności energii kinetycznej od temperatury

Ponadto przeanalizowano wyniki strzelań w pozostałych przypadkach narażeń to jest przy obniżonym ciśnieniu i podwyższonej wilgotności. Zespół badawczy nie odnotował w badanym zakresie wrażliwości systemu na działanie zarówno obniżonego ciśnienia, jak i podwyższonej wilgotności. 


\section{Podsumowanie}

Badania w symulowanych warunkach laboratoryjnych wykazały, że PSSR działa poprawnie w zakresie temperatur od $-40^{\circ} \mathrm{C}$ do $+50^{\circ} \mathrm{C}$, wilgotności względnej $98 \%$ oraz przy obniżonym ciśnieniu do $467 \mathrm{hPa}$. Odnotowano niewielką wrażliwość systemu na zmiany temperaturowe, jednak w całym badanym zakresie system zadziałał prawidłowo i skutecznie. W czasie badań stwierdzono, że możliwe jest zastosowanie w zakładanych warunkach środowiskowych Pneumatycznego Spadochronowego Systemu Ratunkowego na BSP pionowego startu i lądowania.

\section{Literatura}

1. Biała Księga Rynku Bezzałogowych Statków Powietrznych, Ministerstwo Infrastruktury, Warszawa, luty 2019.

2. Grymek S.: Modele strumienia powietrza w pneumatyce. Politechnika Gdańska, Gdańsk 2012.

3. Jastrzębski G.: Description of the pneumatic work cycle of the starting unit of the UAV launcher. Journalof KONES, tom 4, nr 24, 2017.

4. Jastrzębski G.: Impact of opening time of the take-off pneumatic luncher main valve on take-off pressure losses. Journal of KONES, tom 23, nr 4, 2016.

5. Nawrat A.: Modelowanie i sterowanie bezzałogowych obiektów latających. Wydawnictwo Politechniki Śląskiej, 2009.

6. Szczepaniak P., Jóźko M., Włodarczyk J.: Koncepcja pneumatycznego spadochronowego systemu ratunkowego dla BSP pionowego startu i lądowania. Journal of KONBiN, vol. 49, iss. 2, 2019, DOI 10.2478/jok-2019-0026.

7. Szejnach W.: Napędy i sterowanie pneumatyczne. Wydawnictwo Naukowo-Techniczne, 1997.

8. Tomaszek H., Żurek J., Jasztal M.: Prognozowanie uszkodzeń zagrażających bezpieczeństwu lotów statków powietrznych. Wydawnictwo Naukowe Instytutu Technologii Eksploatacji - PIB, 2008. 